\title{
Putting On and Removing the Mask: Layers of Performance Pretence
}

\begin{abstract}
Donning and removing the performer's mask in full view of spectators creates an instant transformation between performer and spectator. Layers of pretence are created or changed which inform or obscure spectator andlor personage understanding. These moments turn and develop the action of the play in performance. Revelations of the personage are created by both donning the mask and removing it. In mumming practices, removal of the mask takes place in order to reveal the 'participant'. In plays, the moment of transformation reveals changed characteristics or identity of the personage. Not only do these kinds of turning points change performerlaudience relationships, but they also affect and condition the structure of the performed event whether this be a play or sequence of mumming. Such pivotal moments are the subject of this article.
\end{abstract}

The simple acts of putting on or removing a mask in front of spectators represent theatrically pivotal moments in the relationships between players and spectators. In those moments of transformation, shared understanding changes. Such changes are those experienced by the performer or spectator within the context of the 'agreed pretence' between player and spectator that are created during performance. ${ }^{1}$ The transmitted changes are those which are perceived to be evident to the player and spectator through intended or unintended performed action. ${ }^{2}$ These kinds of transition establish the parameters within which new conditions may be developed. Changes of this sort may be literal, practical, symbolic — or combinations of these. Spectator understanding of that which went before is no longer evident and the transformation triggers a new condition which replaces the old one. The spectator is now in possession of new information which permits him/her to deny, refute, or challenge former understandings. Alternatively, the spectator is in a position to acknowledge, confirm, or agree with the changed circumstances.

Philip Butterworth (philipbutterworth901@btinternet.com) is a visiting research fellow in the Institute for Medieval Studies, School of History, University of Leeds. 
In this article I propose to examine the fundamental conditions of these pivotal moments and actions through evidence from the canon of English medieval and sixteenth-century plays and the practices of mumming. Because the theatrical or presentational acts of putting on or removing the mask change perceived understandings for personages and audiences, they establish different layers of shared or unshared pretence which influence or condition the developing structure of the play or mumming practice. In addition to referencing the kind of 'mumming' described by Meg Twycross and Sarah Carpenter as 'courtly mumming, ${ }^{3}$ this essay also draws on less formal examples taken from the kind of mumming where participants make 'house visits' and either dance to musical accompaniment or play dice and the more recent practice of performing mummers plays that is reliant on some form of organized and rhyme-spoken text. ${ }^{4}$

I also draw upon eyewitness evidence regarding mumming practice. Although I recognize that these apparently disparate customs and practices differ in eras of time, context, and purpose, they are, and have been, capable of responding to the same kind of moments of transition in donning and removing the mask. Thus, I use evidence drawn from these performed events in their respective periods to explain and analyze the others. The focus of this work is strictly concerned with the moment of transformation and the resultant structural conditioning of plays or mumming in performance. Such simple pivotal moments open up a series of potential layers of pretence from which to develop the theatrical experience of players, personages and spectators.

Throughout, the article uses the word 'personage' in relation to medieval evidence: it replaces any erstwhile reference to the term 'character', for which there is no evidence in medieval records. The term 'character', in its theatrical use, is only recorded in the Oxford English Dictionary Online (OED) from 1664 and its use here would lead to false layers of understanding. Use of the term 'character' in respect of mumming and mummer's plays personæ appears from 1777 in John Brand's Observations of Popular Antiquities:

In the North there is another Custom used at or about this Time, which if I mistake not, was antiently observed in the Beginning of Lent: The Fool Plough goes about, a Pageant that consists of a Number of Sword Dancers, dragging a Plough, with Music, and one, sometimes two, in a very antic Dress; the Bessy, in the grotesque Habit of an Old Woman, and the Fool, almost covered with Skins, a hairy Cap on, and the Tail of some Animal hanging from his Back: The Office of one of these Characters is, to go about rattling a Box amongst the Spectators of the Dance, in which he collects their little Donations. ${ }^{5}$ 
Feasibly, therefore, it might seem legitimate to use the term 'character' when discussing named participants in respect of the roles played by mummers. Since 1777, however, theatrical fashion has loaded the term 'character' with different and nuanced meanings. Today, the term is still heavily influenced by the meanings introduced by Constantine Stanislavski. Since performances of mumming and mummers' plays have not been conditioned by consciously adopted theatrical criteria, ${ }^{6}$ the term 'character' is a similarly inappropriate one to use when considering evidence of participants in mumming and mumming plays. Consequently, I shall use the term 'participant' when referring to mumming personnel and 'named participant' when identifying personæ in 'mummers' plays'.

The key factor that determines layers of pretence depends on answers to the following question: does the spectator know the identity of the player who wears the personage's mask? Answers to this question determine the basis on which the most important layering of pretence occurs. Whether the answer is yes or no, different understandings condition the nature of agreed pretence between player and spectator. Further changes of perception develop if the player or the spectator chooses to ignore or make subliminal such changed awareness. Acceptance or rejection of the new state conditions the nature of agreed pretence between performer and spectator. Related questions arise out of the narrative of the play: Does the narrative permit the personages to know the actual identity of other masked personages? If it does, do they acknowledge it? If not, what are the consequences?

Ostensibly, the purpose of the mask is to remove all facial features of the player or personage by covering the face with a 'false face.' 7 Lydgate in his Pilgrimage of the Life of Man refers to 'a ffals vysage' when he provides Glotonye with a vision of Venus who 'Kam rydynge on a swyn savage,/ And in hyr hand a ffals vysage' which she held 'To-fforn hyr Eyen, lyk A targe' in order that 'She gan shroude and hyde hyr fface ... That no man ne myghte espy'.

The ritual or religious purposes of donning the mask may be to imitate, worship, or placate. Theatrical motives for this action are potentially numerous: the simplest of which is to create an identity of a personage or creature that helps to condition the nature of the production or event - whether this is deliberate or unintended. This sort of motive, as we shall see, is one that also affects the developing character of the play or event in performance or presentation. Related to this condition is the fundamental purpose of reassuring an audience of the players' good will in driving forward the agreed pretence through the action of donning or removing the mask in view of the audience. Another motive may concern the conscious disguising of the player or personage so that his former identity is not recognized by other personages or spectators. Through the simple action of 
putting on the mask another represented personage is created. Additionally, it is possible that the newly positioned mask creates a changed state or condition of the same personage. A different sort of motive is concerned with one that lies outside the narrative requirements of the text, or event, in enabling doubling to take place: i.e. permitting one player to play more than one role. ${ }^{9}$ The converse of doubling is one that I term 'halving', where two players alternately play the same masked role. ${ }^{10}$ These sort of actions are brought about by straightforward pragmatic requirements concerned with the number of available players to play the designated parts. ${ }^{11}$

The mask itself may not wholly cover the face: it may simply work as a partial cover. In the same way, beards and wigs may, in different combinations, fulfil the function of the partial mask. The beard predominantly covers the bottom half of the face whereas the mask, often referred to as the half mask, tends to cover the top half of the face: both forms of mask generally leave the player's mouth and lips unobstructed. The same point pertains to the veil. The half mask was one of the relatively standardized masks used by commedia dell'arte troupes. Although the mask mainly creates a visual statement about the personage it may also create changed vocal characteristics if the player's mouth is partially or wholly obstructed as a result of the mask design. Allardyce Nicoll refers to the vocal disadvantages of the full mask in commedia dell'arte use when he states:

the Italian players avoided the employment of full masks and, instead, wore either half-masks which left the mouth free or else partial masks covering only the nose and part of the cheeks. Thus full freedom for the voice was secured. ${ }^{12}$

When the mask is added to or removed from the face or head in view of the audience it promotes a new condition that may become a normal one. The audience is faced with two adjacent states and carries this experience forward in its recognition of the developing character of the play or event. As such, this new condition permits the stimulus to narrative development in respect of plays and mummers' plays although not to the process of house-visit mumming. Here, progress simply concerns the development of sequence without narrative. Donning the mask offers more complex possibilities in promoting allegory, symbolism, metaphor, irony, or mistaken identity. Removal of the mask signals a revelation - but, of whom or what? Is it the player's face? The erstwhile personage's or participant's face? A represented state or condition of the personage? A moral transformation of the personage signifying redemption? Or, a known participant from the locality? Interestingly, a revelation might also be achieved by the personage donning 
a mask. If the personage's face is changed by putting on a mask it may reveal changed aspects of his/her nature: a new persona is therefore revealed to create new spectator understanding. Such changed circumstances may also take place in view of the spectator or through a staged 'appearance'. The instantaneousness of a masked (previously un-masked) or non-masked (previously masked) appearance from an unseen position creates a moment equally pivotal to that created by a witnessed masking or un-masking in full view of the audience. A good example of this sort of transition occurs in the Cornish play The Life of Saint Meriasek, Bishop and Confessor (discussed later), where Constantine appears in the the scene having donned a mask to denote his affliction with leprosy. ${ }^{13}$ Spectators have previously witnessed Constantine without a mask and now with it. Whether he makes an appearance from outside or inside the performance space is unclear but the simple act of donning the mask provides the pivotal moment of transition through spectator recognition of his new condition. Furthermore, the moment of transition also conditions the developing character and structure of the play. The play is now recognized by the audience as one that changes narrative and staging conditions by the adoption of a mask. A potentially similar staged moment of transition is seen in John Bale's A Newe Comedy or Enterlude, Concernyng Thre Lawes of Nature, Moises, and Christe, Corrupted by the Sodomytes, Pharysies, and Papistes (1562). ${ }^{14}$ Here the personification the Law of Nature, who, like Constantine in Meriasek, is afflicted with leprosy, states:

I thynke ye maruayle, to se such alteration At this tyme in me, whom God lefte here so pure ...

By hym haue I gote this sowle dysease of bodye

And as ye se here, am nowe throwen in a leprye. ${ }^{15}$

Immediately before these lines, an explicit stage direction instructs Infidelitas (Infidelity) to leave the scene. There is no equivalent instruction to Law of Nature to enter the scene, so he might already be present in the performance space, although not in the scene. Law of Nature's opening line makes clear his physically changed appearance, but to whom does he make this difference clear? With the 'exit' of Infidelitas there are no other personifications in the scene. He must therefore address the above lines, and the succeeding lines of his speech, to the audience when he says 'I thynke ye maruayle, to se such alteration'. The implication is that he must demonstrate and represent his affliction with leprosy, like Meriasek, by donning a mask. The audience must see a differently represented person through the addition of a mask. Staged appearances do not have to occur from a hidden position; they can come about from a visible place where 
the personage or participant makes it clear to other personages or participants and spectators that he has entered the action. Spectator response is instant at the moment of recognition.

The wearing of a mask also signals to the witness the instigation of a theatrical or social convention. It contributes to the establishment of the performance 'rules of the game'. Not only does the donning of the mask help to set up a theatrical or customary convention but its removal may be used to signal conclusion to the theatrical game. Somewhat ironically, the creation of staging conventions is reinforced through the apparent breaking of such conventions. The masked personage or participant may deliberately attempt to weaken or subvert the convention by leaking clues as to his identity: in effect, teasing or provoking the spectator to engage in guesswork as to his identity. This possibility is a most powerful one in establishing the player/spectator relationship: it creates an active dynamic driven by spectator curiosity.

Inquisitiveness from witnesses of the masked figure arises out of the provision of partial information. Psychological studies into the creation and nature of curiosity 'did not draw attention to, and thus did not explain, certain salient characteristics of curiosity: its intensity, transcience, association with impulsivity, and tendency to disappoint when satisfied'. ${ }^{16}$ So said George Loewenstein, who further interpreted curiosity 'as a form of cognitively induced deprivation that arises from the perception of a gap in knowledge or understanding.'. ${ }^{17}$ If this explanation is applied to the masked figure, where witnesses of him/her therefore know that there is another figure with a different face beneath the mask, he/she presents incomplete information to the spectator by providing 'a gap in knowledge or understanding'.

Spectator inquisitiveness is the central driver to the relationship with the masked personage and participant. Loewenstein explains the human characteristic to want to know who exists under the mask when he says 'Curiosity involves an indissoluble mixture of cognition and motivation', and J. McV. Hunt further explains that curiosity refers to 'intrinsic motivation' and 'motivation inherent in information processing. ${ }^{18}$ The spectator thus attempts to imaginatively prise apart the masked figure from the one underneath in order to process incomplete information with which he/she is presented. Analogous audience curiosity may also be seen in the perceived discrepancy between the player's role and his known or presumed private life. ${ }^{19}$

Terry Gunnell attests to such behaviour in his impressively edited Masks and Mumming in the Nordic Area where he surveys mumming customs in the north 
Atlantic. In his concentration on such events in Shetland he records the following interview with May Sutherland of Unst in 2000:

Just after tea ... once you'd settled in for the night ... dark nights, you know ... and then you'd hear the knock, knock on the door (laughs) ... that's them arriving ... Well, you invited them in, and they came in and ... I mean, the dancing set, they danced ... played ... you could hear the fiddle before they came to the house, you see ... playing as they were approaching the house ... and they came in and danced and so on, and you offered them some refreshment or whatever ... and they either took it or not, I mean you did nae force them to take it ... no, they either took it or not, and if they were ... if they thought they been ... we'd guessed who they were, you see ... then they would maybe take their masks off, and ... veils off, and let us know who they were ... like ... but very often they didn't do that ... They thought, you see, we hadn't guessed who they were, so they were off again (laughs) ... It was the same with the groups, the Black Groliks going in twos and threes, you see ... They would come in and you were always trying to guess who they were and so on, but ... although they were disguised, you could recognise the way they walked or ... the way ... something about them that you thought you recognised, but, of course, sometimes you were wrong altogether (Laughs ) ... [ ... . Very often it was a thing like a ... bit of muslin, or a loose cotton, or something they put over their faces so you didn't know them ... Masks weren't used much then ... they ... Well, no doubt you couldn't really get them so easily here ... so usually it was some bit of cotton or muslin thing over their faces ... They always tried to hide the hair too ... Just ... The idea was that you had to ... I mean, they didn't want you to recognise them, you see (laughs) ... That was all part of the fun, trying to guess who they were ... They didn't speak ... or ... not until they took their masks off ... then ... but while they were masked and so on, they didn't speak because you would recognise the voice, you see ... ${ }^{20}$

This account refers to important observations concerning the layering of pretence. Gunnell appears to faithfully transcribe Sutherland's words and even allude to unspoken responses where he indicates her laughter. On both occasions her 'laughs' appear to be further implied comments upon those which she has just made: they arise from the discrepancy between what she knows and what the mummers appear not to know. She has guessed the identity of the mummers but she does not let the mummers know of this. She also thinks that the mummers are not aware that their identities have been guessed. Understanding and memory of this state of affairs brings about her playful laughter: she thinks she knows 
what the mummers do not know. She acknowledges that her identification of the mummers may be wrong sometimes, however, and she enjoys this thought: 'That was all part of the fun, trying to guess who they were'. These sorts of distinctions provide the game-like structure and mechanism by which mummer and spectator engage. The 'game is up' when the mummer acknowledges that his identity has been discovered and his mask is removed in front of the witnesses.

Sutherland also records that 'while they were masked and so on, they didn't speak because you would recognise the voice, you see'. The vocal silence referred to here is intended to reinforce the purpose of the mask in concealing identity. The combined value of the hidden face together with vocal silence promotes the developing character of the event. Interestingly, one of the definitions of 'mŏmminge' recorded by the Middle English Dictionary (MED) refers to the 'Suppression of the voice'. This sort of intention is implied by the statutes of Henry VIII in 1509-10 where 'An Acte agaynst disguysed p[er]sons and Wearing of Visours' states that

dyvers persones [who] have disgysed and appareld theym, and covert theyr fayces with Vysours and other thynges in suche manner that they sholde nott be knowen and divers of theym in a Companye togeder namyng them selfe Mummers have commyn to the dwellyng place of divers men of honor and other substanciall persones; and so departed unknowen [should be] imprisoned by the space of thre monthes wythowte bayle or maymprys. ${ }^{21}$

To have 'so departed unknowen' also suggests concomitant vocal silence. Such attempted obfuscation is enhanced in some accounts through deliberate attempts to disguise the voice:

I was the first to enter; but I hastily retraced a few steps as soon as I saw the kitchen literally full of beings, whose appearance, being so unearthly, shook the gravity of my muscles, and forced the cold sweat to ooze out from every pore in my body. There they stood like as many statues, one of whom was far above the rest, and of gigantic dimensions. Eyes, mouths, or noses, they had none; nor the least trace of countenance. They kept up an incessant grunt, grunt, grunt, or a noise partly resembling swine and turkey cocks. Their outer garments were as white as snow, and consisted of petticoats below, and shirts on the outside, with sleeves and collars. They were all veiled, and their head dresses or caps were about eighteen inches in height, and made of straw twisted and plaited. Each cap terminated in three or four cones of a crescent shape, all pointing backwards and downwards, with bunches of ribbons of every colour raying from the points of the cones. The spirits, for such they appeared 
to be, had long staves, with which they kept rapping on the floor. Between them and the door stood one as black as 'Horni;' but more resembling a human being than any of the others. His head dress was a South-wester, and he had a keshie on his back. My landlady by this time had considerably recovered and the sight of the keshie tended greatly to allay our doubts, and we all ventured into the kitchen.

Immediately upon our entering the kitchen they formed themselves into pairs and commenced hobbling and dancing. When asked what they wanted the keshie was presented; and in it was a piece of mutton and other eatables. Their chieftain, or leader, muttered in a disguised and gutteral tone of voice, that they would take anything we chose to give them. My landlady gave them some mutton and oatcakes, with which they appeared highly elated, and returned thanks with bows and curtseys; but still kept up the incessant grunting. But before leaving the door, however, they inquired of me, in the same guttural tone of voice, if they should go to the Minister's. 'Certainly,' said I; 'be sure you go there, and give him a specimen of your dancing; for the minister is a very liberal gentleman, and will, I doubt not, fill your keshie.22

The kind of speech referred to here as 'an incessant grunt, grunt, grunt, or a noise partly resembling swine and turkey cocks' in R. Menzies Fergusson, Rambles in The Far North may well have been the kind of speech recorded in other mumming customs and events as 'ingressive speech'. This term refers to the method of vocalizing on the intake of breath as a means of disguising the voice and not the normal egressive practice. ${ }^{23}$

Mumming customs exist in many cultures and their forms vary considerably. ${ }^{24}$ Not all practices employ masks: some make use of blackened faces ${ }^{25}$ and some use veils. ${ }^{26}$ But all customs utilize some form of devised clothing to aid disguise. ${ }^{27}$ Although players in mummers' plays are not always masked there are exceptions to this practice. For instance, Henry Glassie in his All Silver and No Brass concerning mummers' plays in the South Ulster hills of the Irish border offers firsthand examples of this kind of behaviour. ${ }^{28}$ Glassie was concerned that most of the received opinion and knowledge of mummers' plays was textually based. As an ethnologist he knew that

The older scholars had not asked the questions that interested me. They had studied texts of the plays but had largely ignored the players. They had used the texts as prods to speculation about the early history of drama and ritual, but they had paid little attention to the play as performance, as the embodiment of intention, the 
vehicle for meaning. Their probings had been too shallow and narrow. They had not given the play or its people their due. ${ }^{29}$

Thus, the recipient of a Guggenheim fellowship, Glassie spent time on the Irish border recording conversations with former members of mummers' play teams who had performed their plays in local houses at Christmas. A number of the conversations alluded to the surprise, or 'acted surprise', exhibited at the removal of the cone-shaped straw masks worn by the mummers. Glassie describes an interview with one of the former mummers, Peter Flanagan: "'Did the people know who all the mummers were?" P's answer is quick: "Aw they did. You knew the mummers surely. Why not? And even you didn't know them, you knew they were from the same area not too far away — surely between this and Kinawley"'. ${ }^{30}$

In spite of 'the tall straw cones covering their faces', the people in the houses visited by the teams knew, or thought they knew, the identity of the players even though such recognition was not always openly acknowledged or tested. On the other hand, the mummers thought that their identity was completely masked. In another of Glassie's interviews, the former mummer Michael Boyle relates: 'You went into a house, do y'see. You'd see them and know them, but they wouldn't know who you were, when your nose was only out, you, see, and you just peepin through it. Aye' ${ }^{31}$ These discrepancies between what the mummers knew, or thought they knew, and what the witnesses knew, or thought they knew, promote the central dynamic created by these different perceptions to the performed event: these differences condition their resultant relationship.

The preoccupation with identifying the player beneath the mask represents the most common feature inherent in acts of mumming. Although this core element may only mildly affect some spectator responses, in others the guessing activity has become the principal conditioner of the form: the guessing game becomes the form, and in some cases, the purpose: it represents the active participation of the spectator in the build up to the revelation of the player's identity. This construction of the guessing game is witnessed in mumming practices in Ireland, Scotland, Norway and the eastern sea-board of Canada, particularly Newfoundland. ${ }^{32}$

In Ireland, the spectator task of identifying the mummers developed from the guessing game into a naming game. Peter Flanagan outlines the key moment of identification: 'A girl, a young lassie, would shout, "I know ye". If you thought they were only just makin a guess, you'd try to pull back and leave them guessin. They would hear where the band was from, then, if they could recognize one member, they could guess the others. If they did identify you, then, well, most of them would take their hats off'. 33 
Just as the central driver to the mummer/spectator relationship was affected by spectator curiosity, it was also complemented by the mummers' doggedness in denying opportunities for discovery of their identities. Sometimes, the motivation of the mummers to disguise themselves through clothing and their manner of ingressive speaking was conceived 'so as to deceive the people in their houses'. ${ }^{34} \mathrm{It}$ is one thing to attempt disguise; it is another to attempt deception. Such motivation on the part of the mummer provides a vital counterpart to the active curiosity of the spectator.

Clearly, the mask was required to be complete in masking the visual identity of the mummer. Additionally, attempts were made to 'mask' the voice. Glassie observes further: 'If their observations resulted in no identities, the girls would edge over toward the mummers, trying to peek through the less well-made hats, trying to trick them into speaking with their casual voices'. ${ }^{35}$ Attempts to protect mummers' identities by deliberately stifling vocal responses may also be seen in the Norwegian custom of julebukking which also consisted of Christmas house visits. Sonja Innselsæt of the Valdres Folkemuseum records the kind of conversations that took place between the julebukkers and their hosts:

Those being visited wanted to find out who the masqueraders were; they tried to get the visitors to speak and thereby reveal a recognizable voice or characteristic word or expression that would help identify them. The conversation frequently had a standard range, from the weather to where the jukebukks had come from and where they were going next. ${ }^{36}$ Such 'conversation' was conducted by the julebukkers using disguised voices to imitate animals — particularly, the goat. ${ }^{37}$ 'Julebukker' translates as 'Christmas goats'. ${ }^{38}$

More aggressive attempts to conceal identity may be seen in mumming customs in Newfoundland where

Mummers dress in household odds and ends: table cloths, burlap bags, hip boots, torn dresses, battered hats, woollen underwear, long coats, and gloves. Men usually dress as 'generalized' women and women as 'generalized' men. Shapes become blurred as the pile of coats, sweaters, table cloths, and padding reduce individual differences. Veils of various materials completely surround the head and are held in place by battered men's and women's hats. For mummers, a covered face is a necessity. 39 
Here, mummers go to considerable lengths to confuse and mystify their identities by laying false trails for the spectator through their random but careful choice of clothing. They too, use ingressive speech:

As mummers reverse their sexual roles in their dress, so they reverse their speech. On deep gulps of breath, words are swallowed in a rapid monotone of short phrases. Mummers will answer questions about themselves, but they usually sprinkle false clues to their identity among the true. Yet there are other means of determining mummers' identities. The over-all physical appearance of the mummer, though well disguised, is important in this process. The relative height of individuals and the appearance of hands (when they are exposed) are key determiners. The male-female inversion of dress acts as an indicator of sex. Articles of clothing, naturally, are used to identify individuals, although some attempt may sometimes be made to disguise these articles by mixing them and by using them in an unorthodox fashion. ${ }^{40}$

Clearly, the 'guessing game' achieved its apogee in the mumming practices of Newfoundland. ${ }^{41}$ Elsewhere, and in earlier conventions, successfully guessing the identity of the player or personage under the mask was not an end in itself. Where social conventions differed greatly from those found in mumming customs, codes of behaviour dictated the approach to mask removal: such was the etiquette at court.

Edward Hall in his Chronicle of the late 1540s records a number of disguisings at court where masks ('viziers', 'visers', 'visors', and 'visars') were removed at the conclusion of the dancing: 'then the quene plucked of the kynges visar, \& so did the Ladies the visars of the other Lordes, $\&$ then all were knowen'. ${ }^{42}$ This account is typical of a number of such references made by Hall and demonstrates his propensity to put a sympathetic gloss on his observations. Clearly, the presumed intention in removing the 'visars' was to reveal the identity of the mask wearers and Hall is completely supportive of this purpose. It is quite likely, however, that the dancers knew or could work out who the respective wearers were: after all, the participants were essentially members of the same court. ${ }^{43}$ Recognition of characteristic dance steps was the means by which one of the masked mummers was identified in Deep Harbour, Newfoundland: 'Almost immediately, everyone recognized him by his characteristic step, and calling him by name, shouted encouragement as he danced'. ${ }^{44}$

As Sutherland points out above: 'although they were disguised, you could recognise the way they walked or ... the way ... something about them that you thought you recognised'. In the disguisings at court, outlined by Hall, the 
revelation is not likely to have been one of surprise even though those who witnessed removal of the masks may have acted a surprised response. Acting a surprised response adds yet another layer of pretence to the ones already considered. Available evidence does not clarify whether acted responses were meant to be accepted by other masked dancers or spectators, or quietly sanctioned as part of the courtly convention. It is, of course, possible that narrative requirements determined whether the masked dancer was meant to believe such an acted response. Further, an acted response may simply have been the signal of confirmation that the game had ended. Such acted behaviour is not untypical of many responses to the removal of masks. This, after all, is part of the shared enjoyment between player/dancer and spectator - whether this is an overt or covert practice.

The pivotal moment of changed understanding, as indicated earlier, may also occur through the overt change of personality or condition to a given personage. For example, in the Cornish play The Life of Saint Meriasek, Bishop and Confessor, alluded to earlier, at least one mask is recorded to promote the narrative when an explicit stage direction requires 'a vysour aredy apon Constantyn ys face. ${ }^{45}$ The purpose of preparing the 'vysour' is to anticipate the onset of leprosy to Constantine. There are also other stage directions in the play that require someone or something to 'be ready'. ${ }^{46}$ Does the state of readiness take place in or out of view of the audience? And when is the preparatory readiness turned into action?

Some of the so-called stage directions in Meriasek are later, but contemporary, additions to the manuscript. ${ }^{47}$ Whitley Stokes records that 'The colophon states that the manuscript was finished by 'Dominus Hadton' in the year 1504. The whole book is, I think, in his handwriting, but the MS. has been corrected in several places by a subsequent possessor, who also inserted the stage directions to which I have prefixed a bracket, thus: [.. ${ }^{48}$ If Stokes is correct, the text of the manuscript existed before the stage directions were added. Not all the stage directions are presented with a prefixed bracket. Those presented without brackets may be assumed to have been written as part of the original manuscript. But some of the original stage directions are amended and added by the later hand and presented in square brackets by Stokes. ${ }^{49}$ The characteristic qualities of these stage directions contained within the brackets consist of practical requirements of the kind required by players. Hence, these stage directions may be likened to those written into a modern-day stage manager's prompt copy where readiness for forthcoming action is anticipated.

In this case, the 'vysour' provides the representation of Constantin's leprosy. As indicated earlier, spectators have previously witnessed Constantine without a 
mask and now with it. He wears the mask for a long scene (some 487 lines). At the beginning of the scene he says:

Go home, my soldiers,

The Devil to remember you!

There is leprosy on me

Fallen, and I know not how.

Alas, alas!

I am become a leper,

As every one says, ugly.

No one loves to see my face.

(lines 1354-61)

It is at the beginning of this stanza that Constantine must declare himself, through his newly acquired mask, to be a leper. This is the received moment of transformation for both personages and spectators. At the end of this sequence a further explicit stage direction requires the mask to be removed: ' $y$ e vysour away' (line 1835). Constantine's leprosy is thus healed and Silvester says 'Now I do baptize thee / In the name of Mary's Son', and its representation through the mask is removed. This moment of revelation is theatrically enhanced and synchronized by the requirement of an original explicit stage direction that states: 'When he went down into the water of baptism there shone forth a marvellous splendour of light. So thence he came forth clean, and declared that he had seen Christ.'.50

Adding and removing a mask to signify the onset of a disease and its subsequent cure may appear to be simplistic in naturalistic terms but within the convention of representation and didactic purpose the depiction of real life or truth is not sought. Use of the mask to depict an illness, reflected through the condition of the face, represents a staging convention which may be represented elsewhere in the play if consistency of treatment is to be considered. Earlier, a 'Sick Man' declares:
Alas, alas, what thing is this?
On my face is fallen
A frightful disease, no one loves me.
For Christ's sake now help.
In my face is a disease.

(lines 726-8, 737-8)

Meriasek heals the disease by washing the Sick Man's face with water. Then follows a stanza by the Household Slave in which he declares, 'Well healed art thou certainly / Thank sweet Meriasek' (lines 748-9). If the concern for presentational 
consistency is applied to the Sick Man's face through representation of a mask, in the manner applied to Constantine later on, then it is presumably during this stanza that the Sick Man's mask is removed, presumably by Meriasek, in order for him, in the next stanza, to say 'Meriasek, to you much thanks!' (line 753). Since the Sick Man does not leave the focus of the scene during the healing process it is likely, in the event of a mask being used, that its removal takes place in view of the audience. Earlier in the play, Meriasek heals 'A Cripple' and representation of this personage's condition may simply have been demonstrated through his movement. Meriasek also heals the 'The Fever-Patient' whose malady needed to be represented, however. It is possible that the potential use of additional masks in Meriasek may not have been strictly used to signify facial disfigurement but to signal illness. Even so, these considerations are not confirmed through the articulation of explicit stage directions in the manner of 'a vysour aredy apon Constantyn ys face'.

In the preceding examples the players know that they are wearing masks and know of the masks' theatrical purpose. Further layering of pretence may occur, however, when the player knows that he is wearing a mask but his personage does not. Such is the case in Robert Wilson's A Right Excellent and Famous Comedy Called the Three Ladies of London (1584), ${ }^{51}$ which seeks narrative development through the simple staging device of creating the mask in front of the audience. The three ladies of London in Wilson's play are Lucar, Love, and Conscience. Lady Lucar, or Lucre, ${ }^{52}$ is clearly popular with men, and Love and Conscience lament this condition while Fame urges them to exercise patience with the promise of 'a triple crowne' if they remain true to their names. ${ }^{53}$ In their unsuccessful attempts to preserve their integrity both Love and Conscience sink into depths of degradation. Conscience becomes a brothel keeper for Lucar's friends and is forced to sell brooms in order to make ends meet. Lucar's mission is to corrupt Conscience, and she eventually succeeds in this task and requires Vserie to 'steppe in and bringe me the boxe of all abhomination that standes in the window'. Vserie returns 'with a paynted boxe of incke in hys hand'. Lucar opens 'the boxe and $\operatorname{dip}[\mathrm{s}]$ her finger in it, and spotte[s] Co[n]science face. ${ }^{54}$ This symbolic act of spreading spots of ink on Conscience's face to represent her degradation worsens by the sensual stroking of her face by Lucar, who traces her ink-covered finger between the wet ink spots:

The more I doe behold this face, the more my minde doth vaunt:

This face is of fauor, these cheekes are reddy and white,

These lips are cherry red, and full of deepe delight. 
Quicke rowling eyes, her temples hygh, and forhead white as snowe,

Her eye-browes seemely set in frame, with dimpled chinne below:

O how beautie hath adorned thee with euery seemely hew,

In limmes, in-lookes, with all the rest, proportion keeping dew:

Sure I haue not seene a finer soule in eury kinde of part,

I can not choose but kisse them with my lippes that loue thee with my heart. ${ }^{55}$

All the named features of Conscience's face are connected by the ink-covered finger of Lucar, thus creating transformation of Conscience's face into the mask of infection before the audience. Conscience's described beauty is thus disfigured in contrast to the words spoken. Conscience does not become aware of this new mask of degradation until the end of the play when Judge Nemo, who is trialling Lucar, demands of Conscience 'Declare the cause Conscience at large, how thou commest so spotted, / Whereby many by thee hath bene greatly infected'. ${ }^{56}$

The action of creating the mask on Conscience's face, unbeknownst to her, is a powerful visual affirmation of Lucar's motive in corrupting Conscience. Lucar's intention becomes clear to the audience although Conscience is unaware of her growing facial disfigurement. Thus, Lucar knows and sees what the audience knows and sees although Conscience does not know of this changed appearance. ${ }^{57}$ The moment of transformation of Conscience is thus not an instantaneous one but a slow and gradual development leading to a growing audience understanding of the changed circumstances affecting Conscience.

The discrepancy between what the player knows and what his personage knows, when masked, is again recorded in Ralph Willis's The Cradle of Security. The text of this play has not survived but details of its composition are remembered by Willis after witnessing a performance of the play as a young boy. ${ }^{58} \mathrm{He}$ published the description in his Mount Tabor. or Private Exercises of a Penitent Sinner in 1639 when he was $75 .{ }^{59}$ In the description he states, 'At such a play, my father tooke me with him and made mee stand betweene his leggs, as he sate upon one of the benches where wee saw and heard very well'. Since Willis stood between his father's legs it might be presumed, therefore, that the performance took place in the early 1570 s. The text is as follows:

Upon a Stage-play which I saw when I was a child.

In the City of Gloucester the manner is (as I think it is in other like corporations) that when Players of Enterludes come to towne, they first attend the Mayor to enforme him what noble-mans servants they are, and so to get licence for their publike 
playing; and if the Mayor like the Actors, or would shew respect to their Lord and Master, he appoints them to play their first playbefore himselfe and the Aldermen and common Counsell of the City; and that is called the Mayors play, where every one that will comes in without money, the Mayor giving the players a reward as hee thinks fit to shew respect unto them. At such a play, my father tooke me with him and made mee stand betweene his leggs, as he sate upon one of the benches where we saw and heard very well. The play was called (the Cradle of security,) wherin was personated a King or some great Prince with his Courtiers of severall kinds amongst which three Ladies were in speciall grace with him; and they keeping him in delights and pleasures, drew him from his graver Counsellors, hearing of Sermons, and listning to good counsell, and admonitions, that in the end they got him to lye downe in a cradle upon the stage, where these three Ladies joyning in a sweet song rocked him asleepe, that he snorted againe, and in the meane time closely conveyed under the cloaths where withall he was covered, a vizard like a swines snout upon his face, with three wire chaines fastned therunto, the other end whereof being holden severally by those three Ladies, who fall to singing againe, and then discovered his face, that the spectators might see how they had transformed him, going on with their singing, whilst all this was acting, there came forth of another doore at the farthest end of the stage, two old men, the one in blew with a Serjeant at Armes, his mace on his shoulder, the other in red with a drawn sword in his hand, and leaning with the other hand upon the others shoulder, and so they two went along in a soft pace round about by the skirt of the Stage, till at last they came to the Cradle, when all the Court was in greatest jollity, and then the foremost old man with his Mace stroke a fearful blow upon the Cradle; whereat all the Courtiers with the three Ladies and the vizard all vanished; and the desolate Prince starting up bare faced, and finding himselfe thus sent for to judgement, made a lamentable complaint of his miserable case, and so was carried away by wicked spirits. This Prince did personate in the morall, the wicked of the world; the three Ladies, Pride, Covetousnesse, and Luxury, the two old men, the end of the world, and the last judgement. This sight tooke such impression on me, that when I came towards mans estate, it was as fresh in my memory, as if I had seen it newly acted. ${ }^{60}$

Although Willis's memory of the performance largely deals with the action of it, it does not entirely leave out details of the moral representations of the play — nor, indeed, their relevance. No doubt Willis's father helped the young boy to understand the relevance of the personations at the time of the performance for such understanding appears to be intrinsic to the remembrance of the boy's experience. He clearly understood that 'This Prince did personate in the morall, the wicked of 
the world; the three Ladies, Pride, Covetousnesse, and Luxury, the two old men, the end of the world, and the last judgement'. Even so, his visual memory of these representations appears to be that of the young boy whose retained images were of the personages.

Pride, Covetousnesse, and Luxury lull the prince to sleep in the cradle and secretly manoeuvre the 'vizard like a swines snout upon his face'. To describe this manipulation Willis uses the phrase 'closely conveyed' which is a specific term used by jugglers involved in sleight of hand. It refers to the 'real or apparent transference of objects from one location to another that takes place in front of an audience and yet is not perceived by it'. ${ }^{61}$ This conveyance takes place under 'the cloaths where withall he was covered' and symbolizes his animal-like nature as conditioned by Pride, Covetousnesse, and Luxury who each hold on to one of the chains as a visible statement of their influence. When the cloths are removed from the prince, his face is 'discovered' [i.e. revealed] in order 'that the spectators might see how they had transformed him'. The moment of transformation is instantaneous. When the 'two old men'-seemingly comic figures - arrive at the cradle 'then the foremost old man with his Mace stroke a fearful blow upon the Cradle'. This is the signal whereby 'all the Courtiers with the three Ladies and the vizard all vanished'. This sequence is a theatrically staged version of the one conducted by a juggler when he taps a receptacle with his wand to demonstrate that the previously full vessel is now empty: this is the later termed 'Hey Presto' moment. ${ }^{62}$ When the cradle is struck by the mace, the prince appears 'bare faced': his swine-like vizard has disappeared.

The triangular relationship between player, personage, and spectator clearly determines the layers of pretence between these designations. The evidence outlined above makes it quite clear that all three roles may operate in the same pretended state although such pretence might only be shared by the player and the spectator, leaving the personage to operate in a different one. Differently defined conditions permit different knowledge and awareness which either enables individuals to 'be in the know' or remain ignorant. Addition or removal of the mask permits both knowledge and perceived knowledge depending on what any of these individuals know or think they know. It is possible for both player and spectator to operate under different understandings of, and stances to, pretended states. The most theatrically manipulable circumstances are those directed by the play's narrative in conditioning what the personage knows or does not know and perhaps more importantly — what he is allowed to know.

Of course, much modern theatrical use of the masked actor's performance seeks to fuse embodiment of his/her performance with the nature and properties 
of the mask: the player becomes the mask and the mask becomes the player. A quite different relationship existed between player and personage in medieval theatre, however, where performance conventions centred upon representation and not motivated verisimilitude. ${ }^{63}$ Under these conditions, use of the mask served, supported, and reinforced representational stances to performance where it was clear to the spectator that there was a distinction between player and personage. Effectively, the masked personage was promoted as someone different from the player.

This is clearly evident in the structure of mumming customs, whether they be of the kind outlined by Henry Glassie in the Irish-border mumming plays or the house-visiting customs recorded by Halpert and Story in Newfoundland, where each develops the demand for spectator curiosity driven by the need to know who exists under the mask. Both participants and spectators enter into a game-like structure in which the concern for the identity of the person beneath the mask becomes central to the purpose of the performed event. This condition may seem peripheral to the open and declared intention of the event but recorded spectator responses, cited above, demonstrate how pivotal this concern becomes. This type of guessing game is the one most frequently recorded in memories of eyewitnesses. Removal of the mask in view of witnesses consummates the process.

Differences in playing layers helped to promote the developing structural characteristics of the play. In The Life of Saint Meriasek, Bishop and Confessor the nature of the theatrical pretence is conditioned by mask use. Spectators know of Consantine's disease and its healing through the use of his mask. Thus, the terms of reference by which the audience knows of this condition become a structural feature of the play in performance. A modern player, under naturalistic conventions and without a mask, might simply be required to act recovery from the disease whereas the medieval player in The Life of Saint Meriasek was required to represent and demonstrate both the affliction and its cure through donning and removing the mask.

The ground rules of the performed play are established once it becomes clear that masks will be used. Just as the structure of The Life of Saint Meriasek is conditioned by mask use so too is the more dramatically conceived use of masks in The Three Ladies of London. Not only is the use of masks depicted through the daubing of Conscience's face but another use of the mask takes place when an explicit stage direction requires: 'Enter Lucar, and Love with a visard behind'. ${ }^{64}$ The mask held to the back of Love's head is intended to represent and signify the twofacedness of her marriage. Love expresses her regret that her head is 'in monstrous sort', and Lucar asks, 'Is your head then swollen, good mistress Love, I pray you 
let me see'. From her appearance in the scene, Love's mask may be seen but it is a subliminal feature until attention is drawn to it by herself and Lucar. The mask is used in quite a different way to one where removal of a mask is used to reveal information about the personage. In this case, it is the donning of the mask that reveals aspects of Love's condition. Here again, it is the function of the mask that reveals and permits the developing narrative structure of the play in performance.

Although the donning and removal of masks in front of spectators was necessary to the development of the play or mumming event, it was also a means of reassuring unknowledgable spectators of the nature of pretence and exposing the motives of those who put on the work. Even so, it was still possible for masked figures to create disquiet and suspicion among spectators as to their motives in instigating plays. This is why players and expositors sometimes went to some length to placate and prepare the ground for performance, particularly if they were playing to unaccustomed spectators. John Palsgrave in his Comedye of Acolastus prints the following reassurance in the peroration of his play when he states:

I wolde not thou shuldest thynke moste best beholder [\&] most worshypfulle loker vpon vs, nothynge of mysterie to lurke couered here [\&] that there is noo secrete sence or intent, whych here lyeth hydden in couert, vnder our playeng action [\&] vnder the plaienge gesture or settynge forthe of our present matter. ${ }^{65}$

Such reassurance was not necessary for participants in courtly mumming or spectators receiving mummers in their houses. Here, the terms of reference by which players, participants, and spectators could enter into the agreed pretence of performance were accepted prior to its enactment. Here, spectators expected participants to be masked. 


\section{Notes}

1 See Philip Butterworth, Staging Conventions in Medieval English Theatre (Cambridge, 2014), Introduction, https://doi.org/10.1017/CBO9781139058582.

2 For a cogent discussion of the relationship between actual and imaginary realities, see Hans Kreitler and Shulamith Kreitler, Psychology of the Arts (Durham NC, 1972), 333-58.

3 Meg Twycross and Sarah Carpenter, Masks and Masking in Medieval and Early Tudor England (Aldershot, 2002), 151-68.

4 I have avoided use of the word 'traditional' in describing and contextualizing mummers' plays because of the fragile evidence of their ancestry. Evidence of mummers' plays predominantly dates from the nineteenth and twentieth centuries whereas mumming practices date from the fifteenth century. For different kinds of mumming see Twycross and Carrpenter, Masks, chapters 4 and 7.

5 John Brand, Observations on Popular Antiquities: Including the whole of Mr. Bourne's Antiquities Vulgares (London, 1777), 175-6. One of the earliest texts to deal with the English mummers' play is the Revesby Play of 1779. This has been published in facsimile from the British Library Add MS 44870: 1779 as M.J. Preston, M.G. Smith, and P.S. Smith (eds), Morris Dancers at Revesby, Cectal Facsimiles No. 1, Centre for English Cultural Tradition and Language (Sheffield, 1976).

6 Since the last quarter of the twentieth century some of the contemporary English mummers' play teams have adopted more conscious theatrical playing styles while others have retained or adopted declamatory approaches to their presentations. This distinction is clearly evident in the playing of the Midgeley Pace-Egg Play in the Calder Valley in West Yorkshire. The text of this play was written down in the midnineteenth century and is used, with variations, by two local teams: one performance takes place on Good Friday and the other on Easter Saturday. One team from the Brighouse Childrens' Theatre Company plays the text with the kind of exaggeration found in English pantomimes: this is bold, brash, camp and played with sexual innuendo. The other team consists of sixth-form boys from Calder High School. Here, the boys play the text in a declamatory style in which there is no aspiration to polished performance. See H.W. Harwood and F.H. Marsden (eds), The Pace Egg: The Midgeley Version, 2nd edn (Halifax, 1977); Eddie Cass, The Pace-Egg Plays of the Calder Valley (London, 2004); Eddie Cass, The Lancashire Pace-Egg Play: A Social History (London, 2001), 82-5.

7 The term 'false face' occurs in records of Scottish mumming customs. An early reference occurs in a letter to the editor of the Every-Day Book from John Wood 
Reddock of Falkirk concerning guisard performances in Falkirk: 'The grand affair among the boys in the town is to provide themselves with fausse faces, or masks; and those with crooked horns and beards are in greatest demand' see William Hone, The Every-Day Book, 2 vols (London, 1826, 1827), 2. col.18; Terry Gunnell, 'Framing the False Face: Analysing Disguise Traditions', Ulrika Wolf-Knuts and Annikki Kaivola-Bregenhøj (eds), Pathways: Approaches to the Study and Teaching of Folklore (Turku, Finland, 2001), 47-65; Emily Lyle, Galoshins Remembered: A Penny Was a Lot in These Days, Flashbacks (European Ethnological Research Centre and NMS Enterprises Limited — Publishing National Museums Scotland, 2011), 18, 106-7.

8 John Lydgate, The Pilgrimage of the Life of Man, F.J. Furnivall (trans.), EETs es 83 (London, 1901), lines 13089-102.

9 '[T]hey left aside their disguisings \& played bare face, till one Roscius Gallus the most excellent player among the Romaines brought vp these vizards [masks], which we see at this day vsed, partly to supply the want of players, when there were moe parts then there were persons, or that it was not thought meet to trouble \& pester princes chambers with too many folkes. Now by the chaunge of a vizard one man might play the king and the carter, the old nurse $\&$ the yong damsell, the marchant $\&$ the souldier or any other part he listed very conueniently'. George Puttenham, The Arte of English Poesie (London, 1589; sтc: 20519), 26.

10 The principal reason for this convention and practice of two players playing the same role, or 'halving', is that one of the two players may be required to appear in the same scene as the other player when playing a different personage. See Butterworth, Staging Conventions, 56; Barry B. Adams, John Bale's King Johan (San Marino CA, 1969), 114; T.W. Craik, The Tudor Interlude: Stage, Costume, and Acting (Leicester, 1967), 41-2, 88-9; William J. Lawrence, Pre-Restoration Stage Studies (Cambridge MA, 1927), 52; Staging Religious Drama, Peter Meredith and Johns E. Tailby (eds), Raffaella Ferrari, Peter Meredith, Lynette R. Muir, Margaret Sleeman and John E. Tailby (trans.), Early Drama, Art, and Music Monograph Series, 4, Medieval Institute Publications (Kalamazoo MI, 1983), 53-4, 62; David M. Bevington, From Mankind to Marlowe: Growth of Structure in the Popular Drama of Tudor England (Cambridge MA, 1962), 89-91. A potential reason for the practice of halving in mummers plays is sometimes concerned with ensuring a share, or greater share, in the collected money.

11 A clear requirement for doubling occurs in an explicit stage direction in Whitley Stokes (ed.), Beunans Meriasek. The Life of Saint Meriasek, Bishop and Confessor (London, 1872), 106-7: 'And John ergudyn aredy a horse bakke $\mathrm{y}^{\mathrm{t}}$ was $\mathrm{y}^{\mathrm{e}}$ Jusis $\mathrm{w}^{\mathrm{t}}$ constantyn ffor to play $y^{\mathrm{e}}$ marchont' (And John Ergudyn, who was the Justice with Constantine, on horseback ready to play the merchant). 
12 Allardyce Nicoll, The World of Harlequin: A Critical Study of the Commedia dell'Arte (Cambridge, 1976), 41; see 21 and 77 for illustrations. For further illustrations see Pierre Louis Duchartre, The Italian Comedy: The Improvisation Scenarios Lives Attributes Portraits and Masks of the Illustrious Characters of the Commedia dell'Arte, trans. Randolph T. Weaver (New York, 1966); for a comprehensive series of illustrations that include images of half-masks see the 'Portfolio of Illustrations' in Winifrid Smith, The Commedia Dell'Arte (New York, 1964), 291-338.

13 Stokes, Beunans Meriasek, 77, lines 1354-61.

14 John Bale's A Newe Comedy or Enterlude, concernyng Thre Lawes of Nature, Moises, and Christe, Corrupted by the Sodomytes, Pharysies, and Papistes (London, 1562; sTC: 1288), D3v. This is a revision by Bale of his 1548 edition of this work; see also Twycross and Carpenter, Masks and Masking in Medieval and Early Tudor England, 262-3.

15 John Bale, A Newe Comedy or Enterlude, D3v.

16 George Loewenstein, 'The Psychology of Curiosity: A Review and Reinterpretation', Psychological Bulletin 116.1 (1994), 75.

17 Ibid.

18 Ibid, 94-5; J.McV. Hunt, 'Motivation Inherent in Information Processing and Action', O.J. Harvey (ed.), Motivation and Social Interaction: Cognitive Determinants (New York, 1963), 43.

19 Petr Bogatyrev, 'Semiotics in the Folk Theatre', Ladislaw Matejka and Irwin R. Titunik (eds), Semiotics of Art (Cambridge MA, 1976), 47: 'the audience in folk theatre continually confronts the role which an actor-peasant plays with the actor's own private life'.

20 Terry Gunnell (ed.), Masks and Mumming in the Nordic Area (Uppsala, 2007), 31516. I have included only the part of this interview that affects my discussion.

21 Alexander Luders et al (eds), Statutes of the Realm, 11 vols in 12 (London,1810-28), 3.30. $M E D$, 'main-prise' s.v. (a): 'The release of a prisoner on someone's undertaking to act as surety for him, mainprise'.

22 R. Menzies Fergusson, Rambles in The Far North (Paisley and London, 1884), 160-; Dictionary of the Scots Language Online (DSL), 'kishie' s.v.1 'a straw basket or creel'.

23 oED Online, 'ingressive' adj. c. Phonetics: 'Of or pertaining to utterances made while breathing in'; see Anthony D. Buckley, Críostóir Mac Cárthaigh, Séamas Ó Catháin, Séamus Mac Mathúna (eds), Border-Crossing: Mumming in Cross-Border and Cross-Community Contexts (Dundalk, 2007), 119; L.G. Johnson, 'Laurence Williamson', Scottish Studies 6.1 (1962), 57; Herbert Halpert and G.M. Story (eds), Christmas Mumming in Newfoundland (Toronto, 1969), 37-40, 93, 99, 110, 131. 
24 For a typology of mumming see Halpert and Story (eds), Christmas Mumming, 3561.

25 Johnson, 'Laurence Williamson', 56; Lyle, Galoshins Remembered, 17-18, 48, 55, 57, 72, 79, 176; Kathleen Stokker, Keeping Christmas: Yuletide Traditions in Norway and the New Land (Minnesota, 2000), 92, 189; Brian Hayward, Galoshins: The Scottish Folk Play (Edinburgh, 1992), 47.

26 Louis J. Chiaramonte, 'Mumming in "Deep Harbour”: Aspects of Social Organization in Mumming and Drinking', Halpert and Story (eds), Christmas Mumming, 89; J.D.A. Widdowson and Herbert Halpert, 'The Disguises of Newfoundland Mummers', Halpert and Story (eds), Christmas Mumming, 145-64; Gunnell, Masks and Mumming in the Nordic Area, 316.

27 Here, 'disguise' is used in its meaning of concealing identity. For other medieval uses of the term disguise see Butterworth, Staging Conventions, chapter 6.

28 Henry Glassie, All Silver and No Brass: An Irish Christmas Mumming (Bloomington IN and London, 1975).

29 Ibid, xii: see also Vincent Woods, 'At the Black Pig's Dyke', John Fairleigh (ed), Far From the Land: New Irish Plays (London, 1998), xiii, 1, 60.

30 Glassie, All Silver and no Brass 25; Lyle, Galoshins Remembered, 48: 'EL And did people have to guess who you were? / WB Oh, they knew fine, they knew fine who we were. / EL Did they say? / WB No, no, they never said'.

31 Glassie, All Silver and no Brass, 39.

32 Ibid, 90-1; Terry Gunnell, Masks and Mumming in the Nordic Area, 315-17; Christine Eike, 'Masks and Mumming Traditions in Norway', Terry Gunnell (ed.), Masks and Mumming in the Nordic Area, 76; Carsten Bregenhøj and Hanne Pico Larsen, 'Mask and Mumming Traditions in Denmark', Terry Gunnel (ed.), Masks and Mumming in the Nordic Area, 251; J.B. Jukes, Excursions in and about Newfoundland, During the Years 1839 and 1840, 2 vols (London, 1842), 1.220-2; Sir Richard Henry Bonnycastle, Newfoundland in 1842, 2 vols (London, 1842), 2.138-40; Halpert and Story (eds), Christmas Mumming, 38, 41, 43, 67.

33 Glassie, All Silver and No Brass, 91.

34 Hayward, Galoshins, 48.

35 Glassie, All Silver and No Brass, 91.

36 Stokker, Keeping Christmas, 96.

37 Ibid, 189.

38 Ibid, 92; comprehensive surveys and analysis of Norwegian Julebukking and related customs in Sweden, Denmark, Finland and Karelia, Estonia, and Greenland occur in Gunnell, Masks and Mumming in the Nordic Area.

39 Halpert and Story (eds), Christmas Mumming, 110. 
40 Ibid.

41 Ibid, 82, 103, 148.

42 Edward Hall, Hall's Chronicle; Containing the History of England, during the Reign of Henry the Fourth, and the Succeeding Monarchs, to the End of the Reign of Henry the Eighth (London, 1809), 724, 516, 595, 597, 719, 735.

43 Twycross and Carpenter, Masks and Masking, 149-50, 168.

44 Louis J. Chiaramonte, 'Mumming in “Deep Harbour”', 87, 94.

45 Stokes, Beunans Meriasek, 76.

46 Ibid, 1.955, 1.1152, 1.1230, 1.1347, 1.1420, 1.1532, 1.1546; 1.1747, 1.1839, 1.1865, 1.1895, $1.2106,1.2627,1.2768,1.3009,1.3640,1.3744,1.3802,1.3941,1.4342,1.4424$.

47 Glynne Wickham, 'The Staging of Saint Plays in England', Sandro Sticca (ed.), The Medieval Drama (Albany NY, 1972), 105-6.

48 Stokes, Beunans Meriasek, v-vi.

49 Ibid, 1.1173, 1.1865, 1.2277, 1.2325, 1.2535.

50 Philip Butterworth, Theatre of Fire: Special Effects in Early English and Scottish Theatre (London, 1998), 8, 78.

51 R.[obert] W.[ilson], A Right Excellent and Famous Comoedy called the Three Ladies of London (London, 1584; sTC: 25784).

52 The spelling of 'Lucar' occurs as such in both the 1584 and 1592 editions. In later editions Lucar is spelt as 'Lucre' although this spelling is the more prominent medieval one. See $O E D$ Online s.v. 'lucre' and $M E D$ 'lucre'.

53 Wilson, Three Ladies of London, A2v.

54 Ibid, E1v SD.

55 Ibid, A2v.

56 Ibid, F3r.

57 See Twycross and Carpenter, Masks, 264-5.

58 Although the text of the play has not survived it is recorded as one of the plays in the repertoire of the Lord Cardinal's Players who played before Thomas More: W.W. Greg, The Booke of Sir Thomas Moore, Malone Society Reprints (Oxford, 1911 [1990]), 31.

59 R.[alph] W.[illis], Mount Tabor. or Private Exercises of a Penitent Sinner (London, 1639; STC: 25752).

60 Willis, Mount Tabor, 110-13.

61 Philip Butterworth, Magic on the Early English Stage (Cambridge, 2005), 49.

62 The term 'Presto' first appears in William Vincent, Hocvs Pocvs Ivnior. The Anatomie of Legerdemain. Or, The Art of Iugling ... (London, 1634; sTC: 13542.5): 'the Operator ... must have strange termes, and emphaticall words, to grace, and adorne his actions, and the more to astonish the beholders', (Br, Bv, B2r, B2v). 
63 Butterworth, Staging Conventions, 94.

64 Wilson, Three Ladies of London, Fiv.

65 John Palsgrave, The Comedy of Acolastus, P.L. Carver (ed.), Eets os 202 (London, 1937), 179. 